\title{
Zarządzanie a cyfrowa transformacja tożsamości instytucji edukacyjnych
}

\author{
Katarzyna Baliga-Nicholson*
}

\begin{abstract}
Przedmiotem artykutu jest ukazanie relacyjności, jaka zachodzi pomiędzy zarzadzaniem organizacja edukacyjna, a przemianami zwiazanymi z transformacją cyfrowa. Analizie zostaja poddane obrazy edukacji, jakie wytaniaja się w obrębie cyfrowych portali wiedzy oraz postawy dotyczace edukacji $w$ istniejacej międzynarodowej organizacji edukacyjnej. Badania jakościowe (wywiady oraz etnografia sieciowa) postużly do sformutowania wniosków dla zarzqdzania organizacja z perspektywy neoinstytucjonalnej. $Z$ badań wynika, iż transformacje cyfrowa należy uznać za katalizator zmian, które sięgaja gtębokich obszarów tożsamości instytucjonalnej, sktaniajac organizacje do redefinicji swoich celów. Konieczność restrukturyzacji tradycyjnie pojętego systemu edukacyjnego staje się wyzwaniem dla zarządzania, wymagajacym nowych strategii, ale przede wszystkim nowej wizji.
\end{abstract}

Słowa kluczowe: zarządzanie, edukacja, neoinstytucjonalizm, transformacja cyfrowa.

Nadesłany: 05.06.17 | Zaakceptowany do druku: 19.12.17

\section{Management and the digital transformation of an institution's identity in the field of education}

The subject of the article is to show the relationship between the management of an educational organization and changes related to digital transformation. Emerging meanings of education present in the digital knowledge portals are analysed in conjunction to attitudes towards education in an international organization. Qualitative research (interviews and network ethnography) allowed the author to draw conclusions related to management theory, from a neo-institutional perspective. The research shows that digital transformation should be considered as a catalyst for changes that penetrate deep areas of institutional identity, prompting organizations to redefine their goals. The need to restructure the traditionally understood educational system becomes a challenge for management, requiring new strategies but, above all, a new vision.

Keywords: management, education, neo-institutionalism, digital transformation.

Submitted: 05.06.17 | Accepted: 19.12.17

JEL: O, P3, P36

\footnotetext{
Katarzyna Baliga-Nicholson - mgr, Uniwersytet Jagielloński, Wydział Zarządzania i Komunikacji Społecznej.

Adres do korespondencji: Uniwersytet Jagielloński, Wydział Zarządzania i Komunikacji Społecznej, Instytut Kultury, 30-348 Kraków, ul. prof. Stanisława Łojasiewicza 4, p. 2.390, e-mail: katarzyna.baliga@doctoral.uj.edu.pl.
} 


\section{Wprowadzenie}

Pedro Domingos (2017) w swojej książce The Master Algorythm zaznacza, że „gdyby algorytmy przestały działać, zakończyłby się świat, jaki znamy obecnie". Domingos udowadnia, jak materia codzienności utkana z algorytmów, które w sposób oczywisty pojawiają się w naszych domach, telefonach, samochodach, wchodzi także w coraz głębsze relacje z człowiekiem. Relacje te stanowią ważny obszar badawczy w obrębie zarządzania i teorii organizacji, ponieważ otwieraja nowe możliwości interdyscyplinarnej wspólpracy, tworząc przestrzeń do rozwoju takich dyscyplin nauki jak cyfrowa humanistyka. Postęp technologiczny dostarcza także wiele różnych narzędzi badawczych, dzięki którym możemy zobaczyć na nowo, wydawałoby sie powszechnie zrozumiałe zjawiska, ale przede wszystkim kreuje on potrzebę stawiania nowych pytań o miejsce człowieka w świecie i rolę tworzonych przez niego instytucji. Fenomen instytucji przeżywa swego rodzaju badawczy renesans w naukach o zarządzaniu i teorii organizacji; pojawia sie w pracach takich autorów jak Barabara Czarniawska, Sabina Siebert czy Roy Suddaby. Zagadnienie instytucji będzie jednak stanowić trzon dociekań tego artykułu z powodu napięcia, jakie kreuje w odniesieniu do cyfrowej działalności człowieka. To napięcie wynika $z$ faktu, iż społecznie tradycyjny, okrzepły byt, jakim jest instytucja, staje przed koniecznościa dokonania rekonstrukcji swojej tożsamości w obliczu skutków rozwoju nowych technologii.

Rozważania nad przemianami w obszarze instytucjonalnym chciałabym odnieść do edukacji - tematu, który dotyczy wszystkich, niezależnie od obszaru geograficznego, który wpływa na kształt przyszłości, a równocześnie wymaga gruntownej przebudowy.

Instytucje edukacyjne zmieniają się opieszale, postrzegając transformację cyfrową jako zagrożenie dla ich stabilizacji. Czy jednak ta stabilizacja jest stanem pożądanym? Czy edukacja, która konstytuuje przecież społeczne My, może trwać w swojej niezmienionej formie?

Edukacja publiczna, jaką znamy obecnie, powstała w XIX w. z potrzeby kształcenia określonego typu człowieka, zdolnego do wydajnej pracy, w określonych warunkach, którego przydatność weryfikują zdobyte tytuły. Nauka w tym systemie szeregowana jest według hierarchii ważności. Front stanowią przedmioty ścisłe, następnie uznawane są przedmioty humanistyczne, potem artystyczne i wreszcie związane z rozwojem sportowym. Przydatność poszczególnych przedmiotów wyraża sie w ich obecności godzinowej w strukturze nauczania, możliwości uzyskania tytułu w ich obrębie oraz prestiżu uczących.

Taki model edukacji, $\mathrm{z}$ niewielkimi tylko różnicami, funkcjonuje na całym świecie. Uproszczeniem byłoby stwierdzenie, że okazał się on dobrym rozwiązaniem. Biorąc pod uwagę XX-wieczne kataklizmy, wyniszczające tempo eksploatacji zasobów naturalnych oraz nadal ogromne nierówności społeczne, chciałoby się powiedzieć, iż model ten przyczynił się do podniesienia wydajności wytwórczej człowieka, niemniej jednak wymaga znacznej przebudowy.

Reformy edukacji nie przynosza zadowalających skutków. Mimo że od lat rośnie wysokość nakładów na edukację w przeliczeniu na ucznia/studenta nie ma znaczącej korelacji między wzrostem wydatków a poprawą jakości kształcenia (Andrzejczyk, 2016). Ken Robbinson jako jeden z najbardziej rozpoznawalnych krytyków dominujacego modelu instytucji edukacyjnych (jego TEDTalk zatytułowane - Do schools kill creativity? - w ciągu ostatnich 11 lat obejrzało niemal 50 milionów użytkowników w ponad 160 krajach), każe szukać braku postepu reform w błednym rozumieniu tego, w jaki sposób ludzie uczą się oraz w ocenie motywów zmian (głównie komercyjnych i politycznych) (Robinson, 2015).

Według Robinsona potrzebujemy dziś zupełnie nowego myślenia o instytucjach edukacyjnych. Wprowadzenie zmian wymaga porzucenia starego, postprzemysłowego modelu edukacyjnego, który opiera się na zasadach i praktykach nieadekwatnych do dzisiejszej rzeczywistości.

„Przemysłowy system nauczania sprawdzal sie przez jakiś czas, ale dziś wykańcza sam siebie oraz wielu ludzi z nim związanych. Ceną, jaka płacimy, jest erozja kultury nauczania." (Robinson, 2015, s. 76).

Nie ulega wątpliwości, że przemiany w instytucjach edukacyjnych, zwłaszcza publicznych, są konieczne, ale należy liczyć się z ich wielorakimi konsekwencjami, które z pewnością będą miały również negatywny 
charakter. Beata Glinka i Przemysław Hensel (2017), w swoich badaniach pokazują, że nawet dobre z założenia strategie - takie, których celem jest poprawa jakości i wydajności pracy w sferze administracji publicznej - mogą mieć negatywny wpływ na tożsamość organizacyjną i prowadzić do wzmocnienia patologii biurokratycznych.

W niniejszym artykule postawiłam dwa pytania badawcze:

1) Jaki obraz edukacji tworzą algorytmy w świecie globalnych, cyfrowych portali wiedzy?

2) Jak zarządza się tworzeniem konstruktu organizacji edukacyjnej w świetle neoinstytucjonalizmu?

\section{Definicje pojęć i ramy teoretyczne}

Powszechne rozumienie pojęcia ,instytucja", podobnie jak próby jego definiowania w naukach społecznych, charakteryzuje interpretacyjna i intelektualna różnorodność. O ile celem artykułu nie jest metodologiczny przegląd tych definicji, o tyle jednak termin wymaga doprecyzowania. Instytucje stanowia przedmiot zainteresowania interdyscyplinarnego obszaru badawczego zwanego instytucjonalizmem. W ich nurcie zwykło się wyodrębniać dwie główne szkoły - klasyczną (instytucjonalizm historyczny) i współczesną (nowy instytucjonalizm bądź neoinstytucjonalizm) (Sadowski, 2014).

W ujęciu klasycznym instytucjonalizm w zarządzaniu rozwijał się w pracach takich badaczy jak Philip Selznick (1996) czy Thorstein Veblen (1971; [1899]), oraz John Commons (1931). Ten nurt był krytyczna odpowiedzią na założenia neoklasycznej ekonomii (Sadowski, 2014). Odrzucał analizę racjonalnie działających jednostek (homo oeconomicus) na rzecz homo socalis (agens-institutionalist), czyli podmiotów, które podlegają regułom wspólnotowym (Woźniak-Jęchołek, 2014). Nurt ten przypisywał nadrzędne znaczenie formalnej strukturze, procedurom biurokratycznym i genezie konstytuowania instytucji, marginalizując jednocześnie wpływ pozainstytucjonalnych czynników (Sadowski, 2014). Jeśli chodzi o definicje instytucji w tym podejściu, koncentrują się one na ujęciu działań ludzkich w obrębie ich powtarzalności i powszechności (Sadowski, 2014).

Nowy instytucjonalizm cechuje różnorodność paradygmatyczna. Cechą wspólną wielu nurtów tego obszaru jest definiowanie instytucji znacznie bardziej ogólnie, niż miało to miejsce w klasycznym ujęciu.

„Nowy instytucjonalizm określa się przy tym
jako nieortodoksyjny - w porównaniu do neo-
klasycznego nurtu głównego - nie w sensie
przypisywania sobie różnych teoretycznych
podstaw, ale raczej w sensie przywrócenia
zainteresowania kwestiami instytucjonalnymi,
które były centralnymi dla klasycznej ekono-
mii politycznej, ale zostały w znacznym stop-
niu zaniedbane i pominięte przez neoklasycz-
ną ortodoksję (Vanberg, 1989).

$\mathrm{Na}$ potrzeby tego artykułu instytucja postrzegana będzie przez pryzmat metafory gry. Taka konwencja pomoże zrozumieć instytucje jako przestrzeń interakcji pomiędzy różnymi aktorami, która, opierając się na zbiorze znaczeń, kreuje swoje własne mity, symbole i postawy (Sadowski, 2014). Udział w grze jest możliwy dzięki dekodowaniu, czyli rozszyfrowywaniu jej reguł (Dovey i Kennedy, 2011). Metafora gry dobrze obrazuje również działanie instytucji w odniesieniu do zarządzania, dlatego że w polu swoich zainteresowań stawia strategię. Instytucja w tej metaforze to po prostu zasady gry w działaniu (North, 1990). Gra to też zabawa, która raczej nie kojarzy się $\mathrm{z}$ instytucjami edukacyjnymi.

,Edukacja według słownikowej definicji jest całokształtem procesów wychowawczych i kształcących (Mróz i Śliwińska, 2013), które mają na celu wychowanie autonomicznych jednostek świadomych swego społecznego uczestnictwa, obdarzonych godnością zdolnych do samodzielnego zgłębiania wiedzy i oraz umiejętnego oceniania zdobytych danych (Brzozowski, 2012). Odnosząc tę rudymentarną w brzmieniu definicję do przedstawionych powyżej ram teoretycznych, można wnioskować, iż instytucje edukacyjne mają na celu porządkować życie społeczne i współpracę między ludźmi, gwarantując stabilizację i ograniczenie niepewności, jaką niesie przyszłość. To założenie jest kluczowe $\mathrm{z}$ perspektywy zarządzania, ponieważ wyróżnia instytucje edukacyjne jako takie, których trwanie gwarantuje ciagłość nie tylko instytucjonalną, lecz także systemową.

\section{Badania i analiza wyników}

Perspektywa badawcza przyjęta w tym artykule opiera się na postrzeganiu rzeczywistości społecznej jako konstrukcji herme- 
neutycznej, czyli takiej, która formuje się z osobistych doświadczeń ludzi i wyłania sie w budowaniu relacji między nimi. Interakcje, które zachodzą pomiędzy różnymi aktorami w obszarze instytucji (a także poza jej formalnymi granicami), stanowią podstawowy budulec sieci relacji w procesie nieustannego negocjowania znaczeń i wartości (Magala, 2015). Hermeneutyka jest też adekwatnym odniesieniem do metafory gry, bo, jak zauważają badacze kultury gier komputerowych, gra jest formą symulacji, która poprzez doświadczanie prowadzi do powstawania strategii (Dovey i Kennedy, 2011).

Precyzujac perspektywe badawczą tego artykułu, chciałabym również przywołać wniosek, jaki formułuje Roman Batko:

„Świat nie składa się li tylko z rzeczy, ale przede wszystkim ze znaczeń. Jest zatem o tyle, o ile dla nas znaczy. Relatywizm, którego doświadczamy, jest doznaniem subiektywnym odmienności świata znaków, która osobniczo nakładamy na obiektywną rzeczywistość. (...) Swiat do nas mówi. Najcześciej słowem, tekstem, który należy odczytać, aby zrozumieć (...)" (Batko, 2013, s. 24-25)

$\mathrm{W}$ badaniach skoncentrowałam swoje wysiłki na ukazaniu obrazu edukacji w możliwie szerokim ujeciu. Dlatego też nie zredukowałam edukacji do kategorii zwiazanych z wiekiem (edukacja szkolna, wyższa itd.), miejscem (edukacja w Polsce, US itd.) ani też przedmiotem (przedmioty humanistyczne, ścisłe itd.). Z tego też powodu do eksploracji zasobów cyfrowych polskie słowo „edukacja” zastapione zostało angielskim „education”. Celem badań było zbudowanie obrazu edukacji, który ma uchwycić jej polifoniczność i fragmentaryczność (Batko, 2013). W swoich badaniach wykorzystałam głównie narzędzia cyfrowe: Google Trends, Google AdWords i dane organiczne z wyszukiwarki Google, dzięki którym analiza sprowadza się do wnioskowania opartego na danych gromadzonych w skali makro.

Obraz, jaki wyłonił się z tego etapu badań, skonfrontowałam $\mathrm{z}$ badaniami, jakie przeprowadziłam przy użyciu platformy Facebook, oraz badaniami w International School of Kraków (ISK), w której brałam udział w sesjach szkoleniowych dla nauczycieli, spotkaniach oraz ceremoniach. Przeprowadziłam również wywiady z 8 nauczycielami i 10 uczniami, oraz liczne obserwacje. Wybór ISK jest celowy. Jest to instytucja, w której pracuję, ale też prowadze w jej strukturze badania kultury organizacyjnej. Szkoła ta działa na bazie programu Interantional Baccalaueate, który jest międzynarodowym programem o globalnym zasięgu; językiem obowiązującym w tej instytucji jest angielski. Instytucja powstała w roku 1997, jako placówka quasi dyplomatyczna; miała wówczas pod opieką siedmioro uczniów. Obecnie szkoła ma status fundacji, a w jej strukturach uczy się 281 uczniów z różnych części świata.

W pierwszej fazie badań nad edukacją $\mathrm{w}$ przestrzeni cyfrowej posłużyłam się danymi z wyszukiwarki Google. Wybierając do badań metawyszukiwarke, chciałam przede wszystkim odnieść się do edukacji jako do pewnego kolektywnego fenomenu i ukazać go w sposób bardzo przedmiotowy, jako zbiór pewnych wyników wyszukiwania.

Wyszukiwarka Google bazuje na algorytmie, który w znacznej cześsci jest chroniony tajemnica, wiadomo natomiast, że zadaniem algorytmu jest wyznaczenie ścieżki następujących po sobie kroków, które maja przyczynić się do rozwiązania zadania - w przypadku wyszukiwarki Google: znalezienia odpowiedzi na zadane pytanie. W tym celu pojawia się ranking stron. Kolejność ich występowania wiąże się z licznymi danymi, takimi jak wiele stron cytuje (zawiera linki) do danej strony, jak często jest ona zmieniana i jak często powtarzają się dane słowa.

Badanie edukacji w przestrzeni cyfrowej zaczęło się od zebrania danych surowych (organicznych) w wyszukiwarce Google. Dane te sprowadzają się do listy stron, które dostarczaja treści ściśle związanej z wyszukiwanym słowem, ale jednocześnie ranking stron odpowiada efektywności, z jaka strony są pozycjonowane. Wizja edukacji, jaka wyłania się w cyfrowej rzeczywistości, nie jest zatem wolna od marketingowego komponentu, który widoczny jest na początku wyszukiwania, w postaci kilku stron, które opłaciły swoją pozycję. Część z tych stron oferuje gotowe materiały do nauki; inne dedykowane są upowszechnieniu nauki w skali świata. Pozostałe strony definiuja edukację (Wikipedia), odsyłają do konkretnych instytucji (rządowe strony ministerstwa edukacji) lub mediów (gazety i telewizja).

W Google AdWords edukacja jest natomiast postrzegana jako zestaw haseł najbardziej zbliżonych do zapytania początkowego. Słowa kluczowe dla edukacji to: 
znaczenie edukacji, strony edukacyjne, wydział edukacji, szkoła, edukacja wyższa, jakość edukacji, edukacja dla wszystkich. Analizując dane, można powiedzieć, że edukacja nie różni się tu bardzo od danych organicznych z metawyszukiwarki Google. Narzędzie Google AdWords sugeruje również słowa kluczowe, którym przyporządkowane są wartości wyrażone w formie monetarnej, gdyż jest to narzędzie głównie marketingowe. Najdroższymi hasłami, kosztującymi pomiędzy 21-8 USD są: edukacja wczesnoszkolna, cyfrowe trendy w edukacji, edukacja online, innowacja w edukacji, stopnie naukowe, odwołania do instytucji nadających stopnie naukowe.

Te słowa kluczowe właściwie można zaliczyć do dwóch kategorii haseł - jedne związane są ściśle z instytucją edukacji w jej najbardziej tradycyjnym ujęciu; drugie odnoszą się do postępu cyfrowego.

Poszukiwanie znaczenia edukacji w globalnym kontekście, czyli we wszystkich krajach w języku angielskim, pomiedzy wrześniem 2016 a wrześniem 2017 było możliwe dzięki użyciu narzędzia Google Trends, które ukazuje edukację jako fenomen o globalnym zasięgu, stanowiący temat zapytań w każdym zakątku świata. To z kolei skutkuje konkretnym rynkowym potencjałem edukacji, który przekłada sie na jej funkcję finansową. Trudno jest powiedzieć coś więcej, patrzac na linie trendu w sali roku, ale zestawienie danych z najczęściej wyszukiwanymi według Google hasłami w roku 2016 (Pokemon Go, iPhone7, Donald Trump) pokazuje, że edukacja jest hasłem niewiele mniej popularnym od tych najczęściej wyszukiwanych.

Jak edukacja jest postrzegana w przestrzeni cyfrowej przez pryzmat bardziej zindywidualizowanych opinii? $\mathrm{Na}$ to pytanie odpowiadaja dane zebrane w duchu etnografii sieciowej, netnography (Langer i Beckman, 2005), w przestrzeni usieciowionych indywidualistów. Jak pisze Manuel Castells (2013, s. 128-129), usieciowieni indywidualiści:

„poszerzaja swoje kontakty towarzyskie, wykorzystujac bogactwo dostepnych sieci komunikacyjnych, czynią to jednak w sposób wybiórczy, konstruując swój świat kulturowy zgodnie $\mathrm{z}$ własnymi upodobaniami i planami oraz zmieniając go wraz z ewolucją osobistych zainteresowań i wartości”.

Zgodnie $\mathrm{z}$ tą perspektywą konsumpcja cyfrowego świata opiera się na tworzeniu struktur społecznych w obrębie różnych rzeczywistości, w których ludzie, komunikując się ze sobą, dają sobie jednocześnie możliwość do wyrażania (a nawet konstruowania) siebie i swoich wartości.

Przykładem budowania wspólnego, usieciowionego świata sa platformy społecznościowe, takie jak Facebook (FB). Tworzą się tu heterogeniczne grupy, w których obrębie widoczna jest owa różnorodność pod wzgledem wielu czynników; demograficznych, geograficznych czy psychograficznych.

Edukacja na platformie społecznościowej badana była poprzez zadanie ogólnego pytania: Czym jest edukacja? Wypowiedziało się 27 osób, w tym niektóre $\mathrm{z}$ nich więcej niż raz.

Dominowały wypowiedzi krytykujące instytucje edukacyjne i wskazujące na potrzebę głębokich reform. Jeden $\mathrm{z}$ respondentów, który na co dzień pełni funkcję dyrektora $\mathrm{w}$ jednej $\mathrm{z}$ większych instytucji edukacyjnych w Bawarii napisał:

„Edukacja powinna przygotowywać do przyszłości, dlatego powinniśmy być bardzo krytyczni w stosunku do tradycyjnie rozumianej edukacji i powinna kiełkować w nas gotowośc do zakończenia wielu $\mathrm{z}$ naszych dawnych praktyk edukacyjnych. Edukacja to mniej nauka przedmiotów, a bardziej nauka myślenia i nabierania kompetencji”.

Inne osoby sugerowały szereg zmian, nawet tak radykalnych jak zaprzestanie testowania i egzaminowania jako źródła opresji; pojawiły się również głosy, że edukacja powinna być bardziej atrakcyjna, dostępna dla wszystkich i wspierająca rozwój kompetencji, zdolności i talentów.

$\mathrm{Z}$ badań przeprowadzonych w instytucji edukacyjnej, ISK, wynika, że edukacja jest rozumiana jako rozwój umiejętności akademickich (intelektualnych) oraz tych związanych z rozwojem osobowości (personalnych). Rozwój akademicki jako jeden z dwóch kluczowych obszarów edukacji w ISK był interpretowany głównie jako zdobywanie wiedzy, dązenie do lepszego rozumienia świata, rozwój kompetencji takich jak analityczne i krytyczne myślenie oraz umiejętność wyszukiwania informacji. Uczestnicy badań podkreślali role rozbudzania ciekawości w edukacji i potrzebę ustawicznego kształcenia.

Jeśli chodzi o rozumienie roli edukacji we wspieraniu rozwoju osobowości, to podkreślano głównie znaczenie rozwoju 
emocjonalnego i samoświadomości. W tym ujęciu edukacja jest rozumiana jako pole do rozwoju konkretnych cech charakteru, takich jak: prawdomówność, życzliwość, empatia. Rozwój osobisty rozumiany był także jako pieleggnowanie takich wartości jak godność, tolerancja, odpowiedzialność za czyny i szacunek do innych.

Dominująca narracja, która wynika $\mathrm{z}$ genezy programu Internationale Baccalaureate, jakim posługuje się szkoła, oscyluje wokół rozważań nad przyszłością budowaną wokół wspólnoty, która będzie nie tylko w stanie akceptować różnorodność, lecz także aktywnie jej poszukiwać i ją wspierać.

Inne warte przytoczenia spostrzeżenia dotyczące edukacji podkreślały potrzebę dążenia do edukacji wyjątkowej, jakościowej (doskonałej), w celu kreowania zaangażowanych obywateli i liderów. Edukacja widziana jest tu jako narzędzie do szerzenia tolerancji, otwartości umysłowej, niezależności i umiejętności krytycznego myślenia.

Obraz edukacji, jaki wyłania się z tej przestrzeni badań, jest mocno powiązany z potrzebą pielegnowania myślenia o życiu w społeczności działającej ponad podziałami narodowymi, w której każdy ma rolę do odegrania, która formułuje się w dialogu $\mathrm{z}$ innymi. Ideałem tego rodzaju edukacji jest Global Citizen, zdolny do współczucia i refleksji.

W podejściu do rozumienia edukacji w ISK dominuje zdecydowanie mniejsza kreolizacja postaw, niż było to widoczne w przestrzeni cyfrowej. Postawy te wynikaja z rozumienia edukacji przez pryzmat misji i wizji, jaką stawia przed sobą instytucja, a także filozofii samego programu nauczania.

\section{Wnioski}

Badania edukacji w wyszukiwarce Google i na platformie społecznościowej FB są przykładem zaangażowania ludzi oraz algorytmów, które budują obraz edukacji w przestrzeni cyfrowej, ale go nie wyczerpują. Obraz ten jest wielowymiarowy. Na pierwszy plan wysuwają się formy płaskie pozbawione ekspresji. Edukacja jest tu konstruktem pozbawionym emocji i pasji, ukazanym za pomocą zuniformizowanych symboli i stereotypowych rekwizytów.
Badając edukację w przestrzeni cyfrowej, gdzie jednostki połączone w sieć wzajemnych powiązań wyrażają swoje przekonania w sposób bardziej zindywidualizowany, można dostrzec, że obraz edukacji ulega transformacji. Nabiera ostrości i wyrazu, który przejawia się $\mathrm{w}$ zaangażowanych postawach, mocnych ocenach i gotowości do zmiany. Platforma FB ma też moc uwalniania nawet radykalnych przekonań, o charakterze rewolucyjnym (postulaty o odejściu od oceniania i testowania). Jest wiec to medium, w którym usieciowione jednostki tworzą przestrzeń do artykułowania mocnych opinii, które zapewne nie mogłyby wybrzmieć w ramach danej instytucji szkoły.

Kolejna płaszczyzna tego obrazu tworzy się w rozmowie bezpośredniej z ludźmi. Tu dominuja zaangażowanie, refleksja i gotowość do zmian, która - jak to podkreślano - towarzyszy spotkaniom odbywającym się na początku roku. W ciągu trwania roku szkolnego nikt natomiast nie ma na to czasu. Do tego presja rodziców, aby ich dzieci osiągały dobre wyniki, powoduje że instytucja nie jest w stanie zachować delikatnej równowagi pomiędzy namysłem a mechaniczną realizacją założeń programowych. Szkoła koncentruje się raczej na dobrym przygotowaniu do trudnych egzaminów. Tym samym, potrzeby reform lub realizacji filozoficznych założeń programu rozbijają się o struktury instytucji.

Transformacja cyfrowa powoduje daleko idące zmiany w relacjach społecznych, które stawiaja instytucje przed koniecznością reform. Na poziomie symbolicznym widoczne są one w sposobie organizowania pracy. Budynek szkoły zastępuje przestrzeń wirtualna, gdzie jest oferowana szeroka gama kursów, w całości online lub hybrydowych. Zmiany instytucji edukacyjnych dotyczą także przeobrażeń, jakie dokonują się na poziomie ról. Edukacja oparta na autorytecie nauczyciela i pasywności uczniów odchodzi na rzecz emancypacji uczniów i prób budowania środowiska opartego na wzajemnym szacunku (szkoły demokratyczne).

W czasach, kiedy maleje zaufanie do instytucji publicznych i komercyjnych, edukacja, w tradycyjnej formie przeżywa również kryzys ponieważ, nawet „dobra” edukacja daje coraz mniejszą gwarancję sukcesu, ale, co chyba bardziej symptomatyczne, edukacja nie nadąża za zmianami, 
jakie zachodzą w jej szeroko pojętym ekosystemie. Maleje więc zaufanie społeczne do tradycyjnie pojętej instytucji edukacyjnej, która pozbawiona jasno sprecyzowanego celu czy wizji, staje się skansenem pewnego sposobu myślenia o człowieku.

Czy oznacza to, że edukacja jest taka jak na zdjęciach w wyszukiwarce Google? Gdzie nadal uczniowie siedzą w ławkach, a uśmiechnięci nauczyciele na tle tablic zadają pytania? Otóż edukacja przechodzi swoją własną rewolucję.

Szerokim strumieniem rozlewa się poza instytucje, w miejsca, gdzie programy i podręczniki pisane cyfrowym atramentem dają wolność wyboru i wiedzę dostosowaną do indywidualnych potrzeb. Taka edukacja funkcjonuje poza rządowymi programami i tradycyjnymi instytucjami szkoły czy uniwersytetu, podważając w ten sposób masowość sytemu edukacji i jego instytucjonalną wyłączność. Wpływa również na poziom heterogenizacji grup ze względu na wiek, doświadczenia, pochodzenie i wiele innych. Edukacja w swojej cyfrowej odsłonie nie jest wolna od wad, ale, co ważne, wspiera tworzenie środowiska zdobywania wiedzy opartego na wzajemnej wymianie, kooperacji sieciowej i dialogu.

Końcowe wnioski, jakie płyną z przeprowadzanych badań, mają ścisły związek z zarządzaniem. Poprzez fakt, że technologie cyfrowe są medium, w którym istniejemy i tworzymy nowe środowiska, odgrywają one również główną rolę w tworzeniu naszej świadomości i tożsamości. Tożsamość cyfrowa, tożsamość instytucjonalna, wreszcie tożsamość indywidualna zaczynają się ze sobą ścierać, awataryzują się i niejednokrotnie alienują. W konsekwencji tworzą pola, w obrębie których dochodzi do istnienia wzajemnie się znoszących postaw, reguł i wartości. Wyzwaniem dla zarządzania jest zatem budowanie takich instytucji, które będą umiały odpowiedzieć na zmieniające się oczekiwania, zachowując swoją instytucjonalną ciągłość.

Technologia zmienia ludzi, wpływając na nasz sposób myślenia i zadawania pytań. Rewolucja informacyjna, która bywa nazywana Czwartą Rewolucją (Floridi, 2014), przyniesie trudne do przewidzenia efekty, co z kolei sprawia, że mnożą się scenariusze przyszłości, a ich różnorodność rozciagga się pomiędzy utopijnym obrazem spełnienia i apokaliptyczną wizją końca. Nie ma więc jasno sprecyzowanego celu czy wizji, które edukacja miałaby osiągnąć i może tu jest jej największy problem, bo jak grać w grę, gdy role są niepewne, symbole zmienne, a mity się nie sprawdziły.

\section{Bibliografia}

Andrzejczyk, A. (2016). Wptyw edukacji na rozwój przedsiębiorczości. Białystok: PWE.

Batko, R. (2013). Golem, Awatar, Midas, Ztoty Cielec: organizacja publiczna w plynnej nowoczesności. Warszawa: Wydawnictwo Akademickie Sedno.

Batko, R. (2015). O pożytkach z czytania literatury (pięknej) w naukach o zarządzaniu. W: B. Nierenberg, Ł. Sułkowski i R. Batko (red.), Zarzadzanie humanistyczne (s. 203-215). Kraków: Wydawnictwo Uniwersytetu Jagiellońskiego.

Brzozowski, T. (2012). Przedsiębiorczość jako postawa wobec innych i świata w kontekście procesu budowania płaszczyzny dla dialogu interdyscyplinarnego. Perspektywa pedagogiczno-kulturowa. Przedsiębiorczość - Edukacja, 8, 115-126.

Commons, J. (1931). Institutional Economics. American Economic Review, 21, 648-657.

Domingos, P. (2017). The Master Algorithm. UK: Penguin Random House.

Dovey, J. i Kennedy. H. (2011). Kultura gier komputerowych. Kraków: Wydawnictwo Uniwersytetu Jagiellońskiego.

Floridi, L. (2014). The 4th Revolution: How the Infosphere Is Reshaping Human Reality. Oxford: Oxford University Press.

Glinka, B. i Hensel, P.G. (2017). Reforms and identities: How relentless pursuit of improvements produces a sense of helplessness among bureaucrats. Journal of Organizational Change Management, 30(2), 142-160. https://doi.org/10.1108/JOCM-052016-0090

Langer, R. i Beckman, S. (2005). Sensitive research topics: netnography revisited. Qualitative Market Research: An International Journal, 8(2), 189-203.

Magala, S. (2015). Humanistyczna wolność czy humanitarna solidarność? (Rozważania o zarządzaniu humanistycznym w społeczeństwach postsocjalistycznych). W: B. Nierenberg, Ł. Sułkowski i R. Batko (red.), Zarzadzanie humanistyczne (s. 23-52). Kraków: Wydawnictwo Uniwersytetu Jagiellońskiego.

Mazurkiewicz, G. (red.) (2014). Edukacja jako odpowiedź. Odpowiedzialni nauczyciele $w$ zmieniajacym się świecie. Kraków: Wydawnictwo Uniwersytetu Jagiellońskiego.

Mróz, T. i Siwińska M. (2013). Stownik terminów ogólnej teorii ksztatcenia. Legnica: PWSZ.

Nierenberg, B., Batko R. i Sułkowski, Ł. (2015). Zarzadzanie humanistyczne, Warszawa: Difin. 
North, D.C. (1990). Institutions, institutional change and economic performance. Cambridge University

Press.

Robinson, K. i Aronica, L. (2015). Kreatywne szkoty. Oddolna rewolucja, która zmienia edukację. Kraków: Element.

Sadowski, I. (2014). Współczesne spojrzenie na instytucje: ewolucja pojęć, problem modelu aktora i poziomy analizy instytucjonalnej. Przeglad Socjologiczy, 63(3), 89-114.

Selznick, P. (1996). Institutionalism "Old" and "New". Administrative Science Quarterly, 41(2), 270-277.
Vanberg, V. (1989). Carl Menger's evolutionary and John R. Common's collective action approach to institutions: a comparison. Review of Political Economy, 1, 335.

Veblen, T. (1971) [1899]. Teoria klasy próżniaczej. Warszawa: PWN.

Woźniak-Jechorek, B. (2014). J.R. Commons vs. O.E. Williamson - Dwie szkoły instytucjonalne i ich dorobek z punktu widzenia ekonomiki rynku pracy. Studia i Prawo Ekonomiczne, 91, 391-408. 